\title{
Efficiency production factor of cayenne pepper farming system in Klungkung Regency, Bali Province
}

\author{
Jemmy Rinaldi ${ }^{1}$, I Ketut Mahaputra ${ }^{1}$, Nyoman Ngurah Arya ${ }^{1}$, Ni Wayan Trisnawati ${ }^{1}$, \\ Suharyanto ${ }^{2}$, Anella Retna Kumala Sari ${ }^{1 *}$ and Eko Nugroho Jati ${ }^{1}$ \\ ${ }^{1}$ Assessment Institute for Agricultural Technology (AIAT) Bali, by Pass Ngurah Rai Street, \\ Pesanggaran, South Denpasar, Denpasar City, Bali Province, Indonesia, 80222 \\ ${ }^{2}$ Assessment Institute for Agricultural Technology (AIAT) Bangka Belitung Islands, Mentok Km.4 \\ Street, Pangkal Pinang, Bangka Belitung Province, 33134
}

\begin{abstract}
Klungkung Regency is one of Cayenne Pepper centre producers in Bali which was declared as a horticulture commodities development area, particularly Cayenne Pepper. Most farmers are still applied traditional technologies on Cayenne Pepper production; hence farmers have limittied knowledge about efficiency of Cayenne Pepper production. This research is aimed to understand the efficiency and inefficiency production factors of Cayenne Pepper farming system in Klungkung Regency, Bali Province. Data were collected using questioners on survey techniques. Number of respondents were 40 farmers, consists of 22 farmers from Getakan Village, Banjarangkan District, and 18 farmers from Gelgel Village, Klungkung District. Collected data were analysed by stochastic frontier approach with front 4.1 analysis tools. Results of this research showed that input factors have positive effect to improve Cayenne Pepper production are land area, potassium $(\mathrm{K})$ and manure fertilizer applications. Whereas input factor have negative effect to Cayenne Pepper production are phosphate $(\mathrm{P})$ fertilizer and ZA application. Meanwhile, social factors have negative effect to inefficiency Cayenne Pepper production is education level of farmers.
\end{abstract}

\section{Introduction}

Agriculture Horticulture commodity is potential commodity which has economic value and high market demand. Sub sector horticulture commodity contribution to agriculture development is tend to increase from year to year which marked by increasing of some macro indicators such as Gross Domestic Bruto (GDP), export volume and agricultural sector employment and exchange rate of farmers [1]. Cayenne Pepper commodity could be mentioned as main national commodity besides that of onion, potato, mango, mangosteen, orange, snake fruit (salak), crystal guava, orchid and chrysanthemum. Cayenne Pepper is popular commodity because it is required by almost all of citizens and could not be separated from daily life due to it was used for cooking therefore its circulation on market is large $[2,3,4,5]$.

\footnotetext{
* Corresponding author: anellaretna@yahoo.com
} 
Cayenne Pepper production in Indonesia is not enough capable to fullfill Cayenne Pepper needs national as result of that Cayenne Pepper import is still necessary about 16000 ton/year. Average Cayenne Pepper national production only reached about 4.35 ton/year, meanwhile its potention can reach 10-20 ton/ha [6]. In 2012, Cayenne Pepper production in Bali was 16.04 thousand per ton by land area was 3.36 thousand hectar. Compared to 2011, production decreased was happen up to 1.02 thousand ton $(-5.95 \%)$. It was caused by productivity decreased up to $0.82 \mathrm{t} / \mathrm{ha}(-14.70 \%)$. These phenomenon was caused by traditionally farming system created low of efficiency farming system level. As result of that, this study aims to understand the efficiency and inefficiency production factors of Cayenne Pepper farming system in Klungkung Regency, Bali Province. The result of this study is expected to solve Cayenne Pepper production decreased problem in Klungkung Regency and able to create policy implication particulary about enhancing production efficiency of Cayenne Pepper farming system in Klungkung Regency.

\section{Materials and methods}

This study was conducted in Getakan Village, Banjarangkan Sub District and Gelgel Village, Klungkung Sub District, Klungkung Regency, Bali Province on Desember 2017. Location was determined purposively by considering Klungkung Regency as one of Cayenne Pepper producer center in Bali and has been declared as area for horticulture commodity development particularly Cayenne Pepper commodity. Collected data in this study consisted of quantitative data from primer data. Primer data was obtained by directly interview with respondents/Cayenne Pepper farmers by using questionnaire.

Farmer samples consisted of 40 of Cayenne Pepper farmers. Econometrica method was utilized to estimate relationship betwen independent variables from a production function in Cayenne Pepper farming system. Method selection was selected by considering (1) goodness of fit, (2) model appropriateness and (3) T-test result of assumption parametric [7,8].

Production analysis used production function model of Stochastic Frontier Cobb-Douglas. Assumption model of production function for Cayenne Pepper farming system in Klungkung Regency was $[9,10]$ :

$$
\begin{aligned}
& \operatorname{Ln} Y=\operatorname{Ln} \beta_{0}+\beta_{1} \operatorname{Ln} X_{1}+\beta_{2} \operatorname{Ln} X_{2}+\beta_{3} \operatorname{Ln} X_{3}+\beta_{4} \operatorname{Ln} X_{4}+\beta_{5} \operatorname{Ln} X_{5}+\beta_{6} \operatorname{Ln} X_{6}+\beta_{7} \operatorname{Ln} X_{7}+\beta_{8} \operatorname{Ln} X_{8} \\
& +v i-u i
\end{aligned}
$$

whereas :

$\mathrm{Y}=$ Cayenne Pepper production $(\mathrm{kg})$

$\beta_{0}=$ Constanta

$\mathrm{X}_{1}=$ Land Area $(\mathrm{Ha})$

$\mathrm{X}_{2}=$ Seed utilization $(\mathrm{kg})$

$\mathrm{X}_{3}=$ Animal manure fertilizer $(\mathrm{kg})$

$\mathrm{X}_{4}=$ Nitrogen $(\mathrm{N})$ fertilizer $(\mathrm{kg})$

$\mathrm{X}_{5}=$ Phosphat $(\mathrm{P})$ fertilizer $(\mathrm{kg})$

$\mathrm{X}_{6}=$ Kalium $(\mathrm{K})$ fertilizer $(\mathrm{kg})$

$\mathrm{X}_{7}=$ ZA fertilizer $(\mathrm{kg})$

$\mathrm{X}_{8}=$ Labor (Man-Day)

$\mathrm{v}_{\mathrm{i}}-\mathrm{u}_{\mathrm{i}}=$ Error term (ui) inefficiency model tehcnique effect

$\beta_{\mathrm{i}}=$ coefficient of assumption model, which $\mathrm{i}=1,2,3, \ldots \mathrm{n}$ 
Coefficient value expected were $\beta_{1}, \beta_{2}, \beta_{3}, \beta_{4}, \beta_{5}, \beta_{6}, \beta_{7}, \beta_{8}>0$. Meanwhile, determinant factor the production inefficiency distribution effect value in this study was built by using this equation model :

whereas :

$$
u i=\delta_{0}+\delta_{1} Z_{1}+\delta_{2} Z_{2}+\delta_{3} Z_{3}+\delta_{4} Z_{4}+w_{1} i t
$$

$u \mathrm{i}=$ Inefficiency effect

$\delta_{0}=$ Constanta

$Z_{1}=$ Age of respondent (year)

$Z_{2}=$ Education level (year)

$\mathrm{Z}_{3}=$ Cayenne Pepper farming system experience (year)

$\mathrm{Z}_{4}=$ amount of family member (people)

$\mathrm{w}_{\text {it }}=$ Error term

$\delta_{\mathrm{i}}=$ coefficient of assumption model, which $\mathrm{i}=1,2,3, \ldots \mathrm{n}$

Coefficient value expected were $: \delta_{1}, \delta_{2}, \delta_{3}, \delta_{4}<0$.

\section{Result and discussion}

\subsection{Determinant factor of Cayenne Pepper production efficiency}

Assumption result by using stochastic frontier model described best practice of respondent farmer on technology level available. Assumption was carried out by using Maximum Likelihood Estimate (MLE) method. According to 8 variables assumed relevant, variables significantly different to Cayenne Pepper production on Klungkung Regency were land area, animal manure fertilizer utilization, phosphor $(\mathrm{P})$ fertilizer utilization, kalium $(\mathrm{K})$ fertilizer utilization and ZA fertilizer utilization. Land area, phospor $(\mathrm{P})$ fertilizer utilization and kalium (K) fertilizer utilization were significantly different at $1 \%$ of $\alpha$ level. Equally important, animal manure fertilizer utilization and ZA fertilizer utilization showed significantly different at $5 \%$ of $\alpha$ level. In contrast, seed utilization, nitrogen $(\mathrm{N})$ fertilizer utilization and labor were not significantly different to Cayenne Pepper production (Table 1).

Table 1. Assumption of production function by using maximum likelihood estimate (mle) method on Cayenne Pepper farming system in Klungkung Regency, Bali, 2017

\begin{tabular}{|c|c|c|c|c|c|}
\hline Parameter & Variable & Coefficient & $\begin{array}{c}\text { Standard } \\
\text { Error }\end{array}$ & \multicolumn{2}{|c|}{ t-Ratio } \\
\hline$\beta_{0}$ & Constanta & 3.43 & 1.00 & 3.42 & \\
\hline$\beta_{1}$ & Land area & 0.58 & 0.17 & 3.29 & $* * *$ \\
\hline$\beta_{2}$ & Seed utilization & 0.035 & 0.15 & 0.22 & $\mathrm{~ns}$ \\
\hline$\beta_{3}$ & Animal manure fertilizer & 0.018 & 0.007 & 2.32 & $* *$ \\
\hline$\beta_{4}$ & N fertilizer & 0.14 & 0.13 & 1.05 & $\mathrm{~ns}$ \\
\hline$\beta_{5}$ & P fertilizer & -5.29 & 1.16 & -4.55 & $* * *$ \\
\hline$\beta_{6}$ & K fertilizer & 5.02 & 1.22 & 4.10 & $* * *$ \\
\hline$\beta_{7}$ & ZA fertilizer & -0.016 & 0.008 & -1.95 & $* *$ \\
\hline$\beta_{8}$ & Labor & 0.13 & 0.13 & 0.99 & $\mathrm{~ns}$ \\
\hline
\end{tabular}

Note : $*$ significantly different at $10 \%$ of $\alpha$ level ; ** = significantly different at $5 \%$ of $\alpha$ level ; *** $=$ significantly different at $1 \%$ of $\alpha$ level 
Influencing factors on Cayenne Pepper production efficiency at $99 \%$ of $\alpha$ level were land area and $\mathrm{K}$ fertilizer utilization (Table 1). P fertilizer utilization showed significantly different to Cayenne Pepper production by negative marked. Assumption result obtained from land use area had 0.58 of coefficient value. These value demonstrated that enhancing of land area used for Cayenne Pepper farming system at 1\% in Klungkung regency (other inputs was not change) capable to increase Cayenne Pepper production which production adding was $0.58 \%$. This result was suitable with research result from $[11,12,13,14,15]$ demonstrated that land area could affect positively to Cayenne Pepper production. Its implication was if farmer would like to enhance Cayenne Pepper production, cultivated land area factor should be increased. Besides, increasing production does not have to be by increasing land area, but can also be done by increasing land fertility [16]. This means that if the land to be cultivated is fertile, then maximum production will be achieved. This is in line with the results of research which states that fertile agricultural land has the highest value because fertile soil determines maximum crop yields [17].

In the same way, assumption result of $\mathrm{K}$ fertilizer utilization gave 5.02 of coefficient value described that enhancig of $\mathrm{K}$ fertilizer utilization at $1 \%$ on Cayenne Pepper farming system in Klungkung regency (other inputs was not change) could increase Cayenne Pepper production which production adding was $5.02 \%$. K fertilizer utilization was most responsive among to other variables due to it had highest coefficient. It was also suitable with research result from $[14,15]$ clarified that $\mathrm{K}$ fertilizer utilization positively impact to Cayenne Pepper production up to $95 \%$. Saptana [18] stated that the higher of K and compost fertilizer dosage given, fruit quality produced would be higher too. If defficient of kalium occured in crops, it would cause growth and development of crops will be disturbed.

On the other hand, P fertilizer utilization had 5.29 coefficient value which mean that increasing of $\mathrm{P}$ fertilizer utilization at $1 \%$ on Cayenne Pepper farming system in Klungkung Regency could reduce Cayenne Pepper production up to 5.29\%. Andayani [15] mentioned that TSP fertilizer utilization negatively affect to Cayenne Pepper production at $99 \%$ of $\alpha$ level. It showed that $\mathrm{P}$ fertilizer utilization on Cayenne Pepper farming system in Klungkung regency has been excessive, moreover it could not be absorbed by crops and even reduce Cayenne Pepper production. If farmers expect to enchance its Cayenne Pepper production, $\mathrm{P}$ fertilizer utilization should be diminished. Merismon [19] stated that farmer's behavior usually increase input factors such as fertilizer, pesticide and labor to avoid production risk. Other research result also demonstrated that production factor utilization on Cayenne Pepper farming system in Baturiti Village, Baturiti Sub District, Tabanan Regency could be categorized not effective and not efficient since production factor utilization of urea, ZA, KCI, TSP, NPK and labor were excessive.

Then, animal manure fertilizer (cow) and ZA fertilizer utilization factors showed positively impact on Cayenne Pepper production at $95 \%$ of $\alpha$ level which cow manure fertilizer utilization had 0.018 of coefficient value. It mean that increasing of cow manure fertilizer utilization at $1 \%$, it can enhance $0.01 \%$ of Cayenne Pepper production. If farmers expect to enhance Cayenne Pepper production, cow manure fertilizer utilization has to enhanced. Utilization of organic fertilizer can significantly increase Cayenne Pepper production $[14,15,20,21,22]$. Organic fertilizer can provide positive result to amount and weight of Cayenne Pepper [23]. Cow manure fertilizer utilization capable to give higher Cayenne Pepper production compared to chicken and pig manure fertilizer [24]. In line with this, the results of research by Wijayanti [25] stated that organic fertilizers had a very significant effect on plant height, number of productive branches, number of fruits per plant and fruit weight per plant and the use of cow manure caused differences in chili growth and yield as indicated by the variable plant height, branching level, fruit length, fruit volume, and dry weight of the stover [26]. 
In any case of ZA fertilizer utilization, result showed that ZA fertilizer application negatively affect to Cayenne Pepper production efficiency by -0.016 of coefficient value. It indicated that increasing of ZA fertilizer application at $1 \%$, it would lead to reduce $0.016 \%$ of Cayenne Pepper production. It demonstrated that ZA fertilizer application in research location has reached maximum and excessive. As same as above result, reference [27,28] said that ZA fertilizer application was not significantly impact to Cayenne Pepper production although had negative coefficient value. It suugested that the excessive of ZA fertilizer application did not has significantly effect. As a case in point, ZA fertilizer application should be reduced to increase Cayenne Pepper production. Otherwise, Subiyono [14] stated that ZA fertilizer application could provide positive effect for increasing Cayenne Pepper production. It can be assumed that ZA fertilizer application on location was not excessive overly.

\subsection{Determinant factor of Cayenne Pepper production inefficiency}

Inefficiency technique function utilized 4 variables of assumed affect to Cayenne Pepper production in Klungkung Regency. Among of these 4 variables, there were two variables which significantly affect namely education level and Cayenne Pepper farming system experience. Among of 2 variables mentioned, Cayenne Pepper farming system experience had significantly effect. Nevertheless, education level variable provide negative impact to inefficiency of Cayenne Pepper farming system in Klungkung Regency.

The age of farmers which negative mark and family member which postive mark were not significantly influence to inefficiency of Cayenne Pepper production in Klungkung Regency. On the contrary, the getting older farmers, inefficiency of Cayenne Pepper production farming system would be lower. Different to farmer's age, the more family member, the inefficiency of production would be more not efficient. In additional, efficiency technique index value was categorized efficient due to create the more higher value than 0.70 as efficiency limit. It caused by average of efficiency value was $92.68 \%$ (Table 2).

Table 2. Inefficiency production function assumption of Cayenne Pepper production by using Frontier in Klungkung Regency, Bali, 2017

\begin{tabular}{|c|c|c|c|c|}
\hline Parameter & Variable & Coefficient & $\begin{array}{c}\text { Standard- } \\
\text { error }\end{array}$ & t-ratio \\
\hline$\delta_{0}$ & Constanta & 0.55 & 1.03 & 0.53 \\
\hline$\delta_{1}$ & Age of farmer & -0.02 & 0.01 & $-1.19 \mathrm{~ns}$ \\
\hline$\delta_{2}$ & Education level & -0.12 & 0.08 & $-1.50^{*}$ \\
\hline$\delta_{3}$ & $\begin{array}{c}\text { Cayenne Pepper farming system } \\
\text { experience }\end{array}$ & 0.02 & 0.02 & $1.37^{*}$ \\
\hline$\delta_{4}$ & Family member & 0.10 & 0.09 & $1.14 \mathrm{~ns}$ \\
\hline sigma-square & 0.11 & 0.02 & 4.27 \\
\hline Gamma & 0.30 & 0.18 & 1.62 \\
\hline Log Likelihood function & & & -7.63 \\
\hline LR test of the one-side error & & \multicolumn{2}{c|}{0.92} \\
\hline mean efficiency
\end{tabular}

Note $: *=$ significantly different at $10 \%$ of $\alpha$ level $; * *=$ significantly different at $5 \%$ of $\alpha$ level $; * * *$ $=$ significantly different at $1 \%$ of $\alpha$ level

Education level significantly impact to inefficiency of Cayenne Pepper production in Klungkung Regency at $10 \%$ of $\alpha$ level by -0.12 coefficient value. It can be clarified that the higher of education level for Cayenne Pepper farming system, inefficiency would be lower or it would be more efficient. Education level provide positive effect to production efficiency since education was able to teach farmer's skill to find out information about production factor application [51,29]. However, Beta and Taena [30] clarified that education level was not able to significantly affect to inefficiency of Cayenne Pepper farming system technique. Based on this result, it could be stated that education level was significantly affect to Cayenne Pepper farming system. The results of other studies also state that farmers with higher 
education will be easier to adopt agricultural technology innovations, especially those related to red chili farming [31]. On other hand, based on result in Klungkung Regency, education level played important role to Cayenne Pepper faming system efficiency. It related by the higher of education level, farmers were predicted would be easier to addopt new technology for enchancing Cayenne Pepper production. Related government and stakeholder requires to fasilitate technical assistance or non formally training to upgrade farmer's knowledge and skill about Cayenne Pepper cultivation technology then it can increase Cayenne Pepper production in Klungkung Regency.

Cayenne Pepper farming system experience also play role to significantly impact to inefficiency Cayenne Pepper production at $10 \%$ of $\alpha$ level in Klungkung Regency due to it had 0.02 of coefficient value. The higher level of farmer's experience in Klungkung Regency, inefficiency of Cayenne Pepper production would be higher too. The longer period of farmer's experience, it will create the lower of Cayenne Pepper farming system efficieny. Other research also strengthen these statement that Cayenne Pepper farming system experience showed negative coefficient value whereas it was not strongly affect to production [2]. It mean that the stronger experience of Cayenne Peppere farming experience, the lower efficiency production. It built assumption that the longer period of farming experience, farmers would be more difficult to addopt new technology for their Cayenne Pepper farming system. Farmers may already feel confident and expert with their knowledge about Cayenne Pepper farming. Mobile phone and the internet facilitate these farmers to find out and learn new knowledge. This is because in cultivating Cayenne Pepper requires special skills therefore experienced farmers will implement good farming practices (eg: weeding at right time, fertilizing with the right dose and controlling pests and diseases by using right targeted pesticides), therefore they will obtain higher production [31]. As a result of, it was necessary to build farmer empowerment include create farming system by implication new technology easily compared to those farming way

\section{Conclusion and recommendation}

Based on above result, it can be concluded that land area, animal manure (cow) fertilizer and $\mathrm{K}$ fertilizer utilization able to positively affect on Cayenne Pepper production in Klungkung Regency. Meanwhile, P and ZA fertilizer utilization negatively impact on Cayenne Pepper production in Klungkung Regency. K fertilizer application was most responsive followed by 5.02 coefficient value indicated that Cayenne Pepper production still could be enhanced by increasing of $\mathrm{K}$ fertilizer utilization.

Inefficieny of Cayenne Pepper production in Klungkung Regency was negatively affected by education level of farmers. Meanwhile, farmer's experience provided positively effect on it.

Acknowledgement. We would like to thank Bali Assessment Institute for Agricultural Technology for funding this research.

Author contribution statement. All authors were main contributors in research implementation and creating the manuscript. Jemmy Rinaldi as people in charge of this research. I Ketut Mahaputra as field coordinator and Nyoman Ngurah Arya as co-field coordinator during research implementation. Ni Wayan Trisnawati and Suharyanto contribute to help the tasks of people in charge of this research. Eko Nugroho Jati and Anella Retna Kumala Sari contribute to the creating research design, research implementation, data collecting, data analysis, drafting the manuscript until officially published. 


\section{References}

1. Badan Litbang Pertanian. Panduan Umum Program Dukungan Pengembangan Kawasan Agribisnis Hortikultura (PUPKAH). Badan Penelitian dan Pengembangan Pertanian, Kementerian Pertanian. (2012)

2. S.H. Chonani, F.E. Prasmatiwi, H. Santoso. Jurnal JIIA, 2, 2 (2014).

3. Kusandriani, Y. dan A. Muharam. Produksi Benih Cabai. Balai Penelitian Tanaman Sayuran, Lembang. $30 \mathrm{hlm}$. (2005)

4. D. Wahyudi, S.S. Tan. Kajian Efektivitas Media Diseminasi dalam Inovasi Teknologi PTT Cabai di Kabupaten Cirebon dan Ciamis, Provinsi Jawa Barat. Prosiding Seminar Nasional Membangun Sistem Inovasi di Pedesaan. Balai Besar Pengkajian dan Pengembangan Teknologi Pertanian, Bogor. (2010)

5. R. Rahmawati, M.R. Deviani, N. Suriani. Jurnal Biologi, 13, 2 (2009).

6. Direktur Jendral Bina Produksi Hortikultura. Statistik Hortikultura Tahun 2010. Dirjen Hortikultura, Departemen Pertanian, Jakarta 125 hal. (2010)

7. Intriligator, M.D. Econometric Models, Techniques and Applications. Prentice-Hall, Inc., Englewood Cliffs. New Jersey. (1978)Koutsoyiannis. 1977. Theory of Econometrics, Second Edition. The Macmillan Press Limited. United Kingdom.

8. W. Nahraeni, S. Hartoyo, Y. Syaukat, and Kuntjoro. Jurnal Pertanian, 3, 1 (2012).

9. R. Burhansyah. Informatika Pertanian, 25, 2 (2016).

10. I G.W.F. Sangurjana, I W. Widyantara, I.A.L. Dewi. E-Jurnal Agribisnis dan Agrowisata, 5, 1 (2016).

11. Duriat, A.S. Hasil Penelitian Cabai Merah TA. 1993/1994. Hlm. 201-305 dalam Prosiding Seminar dan Evaluasi Hasil Penelitian Hortikultura. Pusat Penelitian Hortikultura, Jakarta. (1995)

12. A. Saptana, H.K. Daryanto, Kuntjoro. Jurnal Agro Ekonomi, 28, 2 (2010).

13. F. Harahap. Economics Development Analysis Journal (EDAJ), 2, ,4 (2013). .

14. K. Subiyono. Jurnal Agro Ekonomi, 23, 2 (2005).

15. S.A. Andayani. Mimbar Agribisnis, 1, 3 (2016).

16. I.M.A.D. Saputra, and I.W. Wenagama. E-Jurnal Ekonomi Pembangunan Unud, 8, 1 (2019).

17. A. Nurwanto, R. Soedradjad, N. Sulistyaningsih. Jurnal AGRITROP, 15, 2 (2017).

18. A.Saptana, H.K. Daryanto, Kuntjoro. Jurnal Manajemen \& Agribisnis, 7, 2 (2010).

19. Merismon. Pertumbuhan Hasil Tanaman Cabai Besar (Capsicum annum L.) di Tanah Gambut yang Diberi Pupuk Kandang Kotoran Sapi. Prosiding Seminar Nasional Lahan Suboptimal 2014, Palembang 26-27 September 2014. ISBN;979-587-529-9. (2014)

20. Maruli, Ernita, H. Gultom. Jurnal Dinamika Pertanian, 27, 3 (2012).

21. M. Hatta. Jurnal Floratek, 6, (2011).

22. A. Wartapa, S. Sugihartiningsih, S. Astuti, Sukadi. Jurnal Imu-Ilmu Pertanian, 6, 2 (2010).

23. Ajak, R.I.C.O. Taolin. Jurnal Savana Cendana, 1, 3 (2016).

24. E. Nurahmi, T. Mahmud, and S.S. Rosiana. Jurnal Floratek, 6, 2 (2011).

25. M. Wijayanti, M.S. Hadi, and E. Pramono. Jurnal Agrotek Tropika, 1, 2 (2013).

26. D.S. Wahyuni, E. Djuwendah. Jurnal Ilmu Pertanian dan Peternakan, 6, 2 (2018).

27. A. Anjarwati, E. Istiyanti, U.Hasah. Jurnal Surya Agritama, 2, 1 (2013).

28. I. Nofita, S. Hadi. Jurnal JSEP, 8, 3 (2015).

29. Susanti. Efisiensi Teknis Usahatani Cabai Merah Keriting di Kabupaten Bogor: Pendekatan Stochastic Production Frontier. Thesis Sekolah Pascasarjana Institut Pertanian Bogor. (2014)

30. K. Beta, and W. Taena. Jurnal Agribisnis Lahan Kering, 3, 1 (2018). 
31. J. Mariyono, Sumarno. Journal of Agribusiness in Developing and Emerging Economies, 5, 1 (2015). 